\title{
Construction of Physical Fitness Norms for Girl Students of Social Welfare Schools in Andhra Pradesh- A Pilot Study
}

\author{
Dileep Kumar Songa, Prof Y. Kishore and DrK. Sivananda
}

\begin{abstract}
Many students strive to attain excellence in sport. However, talent identification and development programs need uniformly accepted theoretical framework to guide current practices. Find the talent in pre-adolescents, more specific with students of social welfare schools. These norms can be used to grade the students based on physical fitness parameters. The constructed physical fitness norms for "Social Welfare schools in Andhra Pradesh" for sports talent identification and fitness development programmes. Researcher has conducted a battery tests for 339 students from 6th class to 10th class girl students of Social welfare Schools of Andhra Pradesh who attended the summer camp representing schools from urban and semi urban areas of Andhra Pradesh. Selected physical fitness variables i.e. Speed, strength, agility, flexibility. Test items were taken from AAPHER youth fitness battery. Mean, standard deviation and percentile were computed by using, "RProgram". The data indicates that the mean value 50mts run of the 9th class students was best i.e. 9.12 seconds. The result of the Bend \& reach test indicates that the mean flexibility of 10 th class students was recorded as highest followed by 8 th class. Medicine ball put indicates that the improvement of performance among the classes was gradually progressive from lower class to higher class. Standing broad jump results indicate that there was positive increase in performance from lower class to higher class except the students of 10th standard. In the $6 \times 10 \mathrm{mts}$ shuttle run, the data indicates that there was a gradual improvement of performance from 6 th to 9th class. The performance of 10 students was less than the 9th students. The vertical jump results indicated that there was only a small improvement in the performance from 6th and 7th class students and the increment was gradually positive from 7 th to 9 th class and there was a decrease in performance in case of 10th class students. The percentiles were computed to provide a 10 point scale for each of the variable for each of the class i.e. 6th, 7th, 8th, 9th and 10th classes.
\end{abstract}

Index Terms - physical fitness norms, social welfare, talent identification, medicine ball put.

Manuscript revised July 30, 2020 and published on August 10, 2020

S. Dileep Kumar, University College of Physical Education and Sports Sciences, Acharya Nagarjuna University, Guntur, Andhra Pradesh, India.

Prof. Y. Kishore, University College of Physical Education and Sports Sciences, Acharya Nagarjuna University, Guntur, Andhra Pradesh, India. Dr. K. Sivananda, Sri Krishnadevaraya University, Ananthapuramu, Andhra Pradesh, India.

\section{INTRODUCTION}

Talent is "an individual's potential for success in a domain". Talent identification and development processes are important components of many sports and games. Talent is difficult to define and its identification may rely on intuitive judgments. Many students strive to attain excellence in sport. However, talent identification and development programs need uniformly accepted theoretical framework to guide current practices. Further, there is a need to develop programs to grade the students on the basis of their physical fitness.

This study helps to find the talent in pre-adolescents, more specific with students of social welfare schools. Further, these norms can be used to grade the students based on physical fitness parameters.

\section{STATEMENT OF THE PROBLEM}

The purpose of the study was to construct physical fitness norms for "Social Welfare schools in Andhra Pradesh" for sports talent identification and fitness development programmes.

\section{A. Delimitations}

The study was delimited in the following aspects.

$>$ Only the girl students of classes 6 th to $10^{\text {th }}$ were taken as subjects.

$>$ The study was conducted only for the students of social welfare schools in Andhra Pradesh.

$>$ The study was confined to develop physical fitness norms.

\section{B. Limitations}

The study was limited in the following aspects.

$>$ The parental back ground and socio-economic status of the subjects were not considered for this study.

$>$ The factors like food habits, weather conditions, diet, life style and family back ground were beyond the control of the investigator.

\section{Objective of the study}

The objective of the study was Construction of physical fitness norms for girl students of social welfare schools in Andhra Pradesh.

\section{Significance of the study}

This study helps the physical education teachers of social welfare schools to assess the physical fitness level of the students. Further, it helps the physical education teacher to encourage the physically fit students to participate in 
competitive sports. Talented students can be identified through these norms. Conduct of tests based on these batteries gives opportunity for the students to know their fitness levels and motivate them to improve their fitness levels.

\section{Methodology}

Researcher has conducted a battery tests for 339 students. Testers and the students were oriented before the conduct of tests.

\section{A. Selection of subjects:}

In the present study, the researcher has chosen $6^{\text {th }}$ class to $10^{\text {th }}$ class girl students of Social welfare Schools of Andhra Pradesh who attended the summer camp representing schools from urban and semi urban areas of Andhra Pradesh.

\section{B. Selection of variables}

The following test items were chosen to test the physical fitness variables i.e. Speed, strength, agility, flexibility. Test items were taken from AAPHER youth fitness battery.

\begin{tabular}{cll}
\hline S.No. & Physical Fitness test & \multicolumn{1}{c}{ Units } \\
\hline 1 & 50mts run & Time $(\mathrm{sec})$ \\
2 & Bend \& Reach & Centimeters $(\mathrm{cm})$ \\
3 & M Ball Throw & Centimeters $(\mathrm{cm})$ \\
4 & Standing Broad Jump & Centimeters $(\mathrm{cm})$ \\
5 & $6 \times 10$ shuttle run & Time $(\mathrm{sec})$ \\
6 & Vertical Jump & Centimeters $(\mathrm{cm})$ \\
\hline
\end{tabular}

\section{Collection of Data}

Researcher has conducted the tests with the assistance of physical education teachers and coaches. Researcher had given orientation to the testers to conduct the tests. Standard equipment was used to conduct the tests. The necessary formats to record the data were provided to the testers. Tester's reliability was established by conducting test re test method.

\section{Instrument reliability}

The equipment used was Stopwatches, Steel tapes, $1 \mathrm{~kg}$ medicine ball, marking cones and stool. All the equipment used was standard equipment.

\section{E. Statistical procedure:}

The raw data was collected by conducting the following tests i.e. 50mts run, bend and reach test, medicine ball put, standing broad jump, 6x10 shuttle run and vertical jump. The data was pooled separately for each class i.e. $6^{\text {th }}, 7^{\text {th }}, 8$ th, $9^{\text {th }}$ and $10^{\text {th }}$ class.

Mean, standard deviation and percentile were computed by using, "R- Program".

\section{ANALYSIS OF THE DATA AND RESULT OF THE STUDY}

The following tables and graphs explain the data.

\begin{tabular}{lllllll}
\hline 6th & 50mts (in sec) & 71 & 9.89 & 0.79 & 8.04 & 11.97 \\
7 th & 50mts (in sec) & 78 & 9.83 & 9.73 & 8.05 & 12.75 \\
8 th & 50mts (in sec) & 82 & 9.42 & 9.32 & 8.01 & 11.88 \\
9 th & $50 \mathrm{mts}$ (in sec) & 91 & 9.12 & 9.02 & 7.05 & 11.29 \\
10 th & $50 \mathrm{mts}$ (in sec) & 17 & 9.33 & 9.22 & 8.01 & 11.68 \\
\hline
\end{tabular}

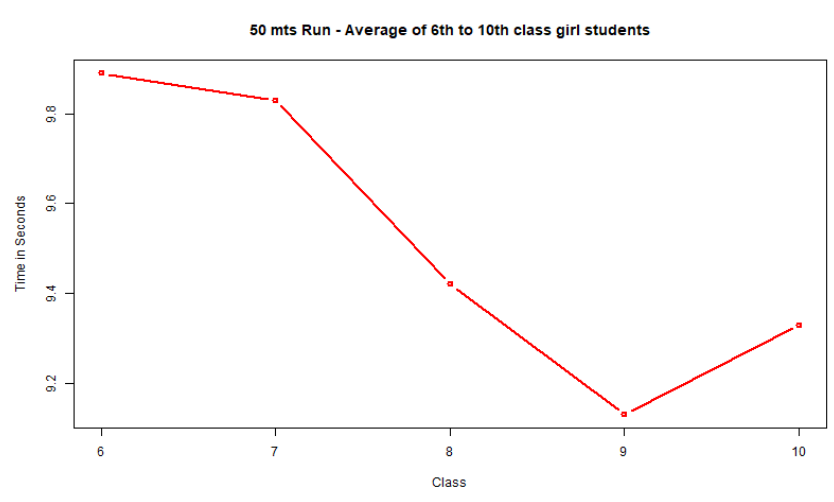

Fig. 1. 50mts Run - Average of $6^{\text {th }}$ to $10^{\text {th }}$ class girl students.

Table 2: Norms For 50mts Run Of All Classes

\begin{tabular}{|c|c|c|c|c|c|}
\hline \multirow{2}{*}{$\begin{array}{c}\text { Mar } \\
\text { ks }\end{array}$} & 6th Class & 7th Class & 8th class & 9th class & 10th class \\
\hline & $\begin{array}{c}\text { Time in } \\
\text { sec }\end{array}$ & $\begin{array}{c}\text { Time in } \\
\text { sec }\end{array}$ & $\begin{array}{c}\text { Time in } \\
\text { sec }\end{array}$ & $\begin{array}{c}\text { Time in } \\
\text { sec }\end{array}$ & $\begin{array}{c}\text { Time in } \\
\text { sec }\end{array}$ \\
\hline 10 & $8.04-8.43$ & $8.05-8.52$ & $8.01-8.40$ & $7.05-7.47$ & $8.01-8.38$ \\
\hline 9 & $8.44-8.83$ & $8.53-8.99$ & $8.41-8.78$ & $7.48-7.90$ & $8.39-8.74$ \\
\hline 8 & $8.84-9.22$ & $9.00-9.46$ & $8.79-9.17$ & $7.91-8.32$ & $8.75-9.11$ \\
\hline 7 & $9.23-9.61$ & $9.47-9.93$ & $9.18-9.56$ & $8.33-8.75$ & $9.12-9.48$ \\
\hline 6 & $\begin{array}{l}9.62- \\
10.01\end{array}$ & $\begin{array}{l}9.94- \\
10.40\end{array}$ & $9.57-9.95$ & $8.76-9.17$ & $9.49-9.85$ \\
\hline 5 & $\begin{array}{c}10.02- \\
10.40\end{array}$ & $\begin{array}{c}10.41- \\
10.87\end{array}$ & $\begin{array}{l}9.96- \\
10.33\end{array}$ & $9.18-9.59$ & $\begin{array}{l}9.86- \\
10.21\end{array}$ \\
\hline 4 & $\begin{array}{c}10.41 \text { - } \\
10.79\end{array}$ & $\begin{array}{c}10.88- \\
11.34\end{array}$ & $\begin{array}{c}10.34- \\
10.72\end{array}$ & $\begin{array}{l}9.60- \\
10.02\end{array}$ & $\begin{array}{c}10.22- \\
10.58\end{array}$ \\
\hline 3 & $\begin{array}{c}10.80- \\
11.18\end{array}$ & $\begin{array}{c}11.35- \\
11.81\end{array}$ & $\begin{array}{c}10.73- \\
11.11\end{array}$ & $\begin{array}{c}10.03- \\
10.44\end{array}$ & $\begin{array}{c}10.59- \\
10.95\end{array}$ \\
\hline 2 & $\begin{array}{c}11.19 \text { - } \\
11.58\end{array}$ & $\begin{array}{c}11.82- \\
12.28\end{array}$ & $\begin{array}{c}11.12- \\
11.49\end{array}$ & $\begin{array}{c}10.45- \\
10.87\end{array}$ & $\begin{array}{c}10.96- \\
11.31\end{array}$ \\
\hline 1 & $\begin{array}{c}11.59- \\
11.97\end{array}$ & $\begin{array}{c}12.29- \\
12.75\end{array}$ & $\begin{array}{c}11.50- \\
11.88\end{array}$ & $\begin{array}{c}10.88- \\
11.29\end{array}$ & $\begin{array}{c}11.32- \\
11.68\end{array}$ \\
\hline
\end{tabular}

Table-3: Result of Bend \& Reach

\begin{tabular}{ccccccc}
\hline Class & Variable & $\mathbf{n}$ & mean & sd & min & max \\
\hline 6th & Bend \& Reach $(\mathrm{cms})$ & 71 & 4.775 & 3.59 & 0 & 14 \\
7th & Bend \& Reach $(\mathrm{cms})$ & 78 & 5.35 & 3.82 & 0 & 14 \\
8th & Bend \& Reach $(\mathrm{cms})$ & 82 & 7.549 & 4.48 & 0 & 18 \\
9th & Bend \& Reach $(\mathrm{cms})$ & 91 & 7.286 & 4.15 & 0 & 18 \\
10th & Bend \& Reach $(\mathrm{cms})$ & 17 & 8.059 & 3.85 & 1 & 16 \\
\hline
\end{tabular}

Table-1: Result Of 50mts Run

\begin{tabular}{lllllll}
\hline Class & Variable & n & mean & sd & min & max
\end{tabular}




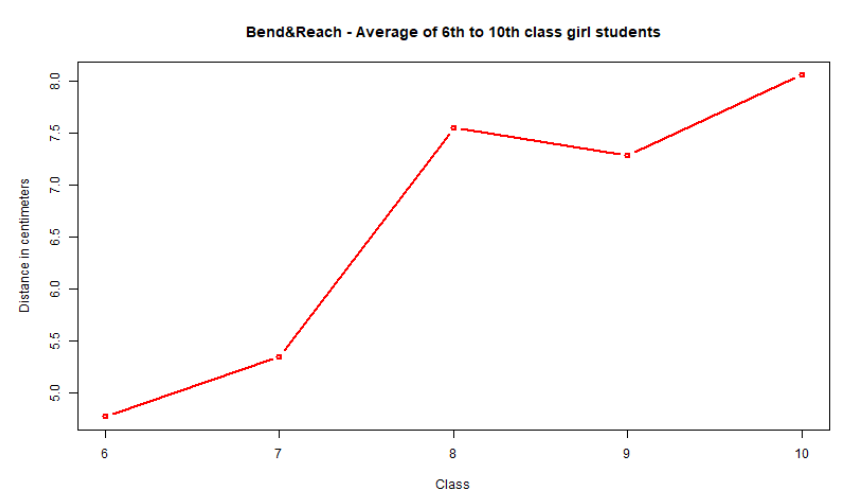

Fig. 2.Bend \& Reach - Average of $6^{\text {th }}$ to $10^{\text {th }}$ class girl students.

Table-4: Norms for Bend and Reach

\begin{tabular}{cccccc}
\hline \multirow{2}{*}{ Marks } & 6th Class & 7th Class & 8th class & 9th class & $\begin{array}{c}\text { 10th } \\
\text { class }\end{array}$ \\
\cline { 2 - 6 } & $\begin{array}{c}\text { Distance } \\
\text { in cm }\end{array}$ & $\begin{array}{c}\text { Distance } \\
\text { in cm }\end{array}$ & $\begin{array}{c}\text { Distance } \\
\text { in cm }\end{array}$ & $\begin{array}{c}\text { Distance } \\
\text { in cm }\end{array}$ & $\begin{array}{c}\text { Distance } \\
\text { in cm }\end{array}$ \\
\hline 10 & $13-14$ & $13-14$ & $17-18$ & $18-16.2$ & $16-14.5$ \\
9 & 12 & 12 & $15-16$ & $16.2-$ & $14.5-13$ \\
& & & & 14.4 & \\
8 & $10-11$ & $10-11$ & $13-14$ & $14.4-$ & $13-11.5$ \\
& & & & 12.6 & \\
7 & 9 & 9 & $11-12$ & $12.6-$ & $11.5-10$ \\
6 & 8 & 8 & 10 & $10.8-9$ & $10-8.5$ \\
5 & $6-7$ & $6-7$ & $8-9$ & $9-7.2$ & $8.5-7$ \\
4 & 5 & 5 & $6-7$ & $7.2-5.4$ & $7-5.5$ \\
3 & $3-4$ & $3-4$ & $4-5$ & $5.4-3.6$ & $5.5-4$ \\
2 & 2 & 2 & $2-3$ & $3.6-1.8$ & $4-2.5$ \\
1 & 1 & 1 & 1 & $1.8-0$ & $2.5-1$ \\
\hline
\end{tabular}

Table-5: Result of Medicine Ball Put

\begin{tabular}{ccccccc}
\hline Class & Variable & n & mean & sd & min & max \\
\hline 6th & Medicine Ball put $(\mathrm{cms})$ & 71 & 281.5 & 57.18 & 105 & 435 \\
7th & Medicine Ball put $(\mathrm{cms})$ & 78 & 337.1 & 72.43 & 210 & 575 \\
8th & Medicine Ball put $(\mathrm{cms})$ & 82 & 376.2 & 67.45 & 222 & 535 \\
9th & Medicine Ball put $(\mathrm{cms})$ & 91 & 403.5 & 68.26 & 226 & 564 \\
10th & Medicine Ball put $(\mathrm{cms})$ & 17 & 438.8 & 60.3 & 326 & 580 \\
\hline
\end{tabular}

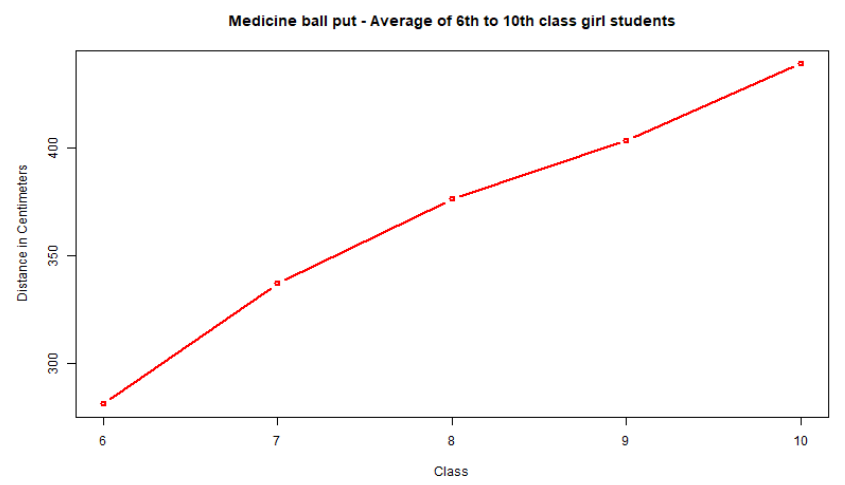

Fig. 3. Medicine ball put - Average of $6^{\text {th }}$ to $10^{\text {th }}$ class girl students.
Table-6: Norms for Medicine Ball Put

\begin{tabular}{|c|c|c|c|c|c|}
\hline \multirow[b]{2}{*}{ Marks } & 6th Class & 7th Class & 8th class & 9th class & 10th class \\
\hline & $\begin{array}{l}\text { Distance } \\
\text { in cm }\end{array}$ & $\begin{array}{l}\text { Distance } \\
\text { in cm }\end{array}$ & $\begin{array}{c}\text { Distance } \\
\text { in } \mathbf{~ c m ~}\end{array}$ & $\begin{array}{c}\text { Distance } \\
\text { in } \mathbf{~ c m ~}\end{array}$ & $\begin{array}{c}\text { Distance } \\
\text { in cm }\end{array}$ \\
\hline 10 & $402-435$ & $539-575$ & 504-535 & $530-564$ & $555-580$ \\
\hline 9 & $369-401$ & $502-538$ & $472-503$ & $497-531$ & 530-554 \\
\hline 8 & $336-368$ & $466-502$ & $441-471$ & $463-496$ & $504-529$ \\
\hline 7 & 303-335 & $429-465$ & $410-440$ & $429-462$ & $478-503$ \\
\hline 6 & 270-302 & $393-428$ & $379-409$ & $395-428$ & $453-477$ \\
\hline 5 & $237-269$ & $356-392$ & $347-378$ & $361-395$ & $428-452$ \\
\hline 4 & 204-236 & $320-355$ & $316-346$ & $327-360$ & $402-427$ \\
\hline 3 & $171-203$ & 283-319 & $285-315$ & $294-326$ & $377-401$ \\
\hline 2 & $138-170$ & $247-282$ & $253-284$ & $260-293$ & $351-376$ \\
\hline 1 & $105-137$ & $210-246$ & $222-252$ & $226-259$ & $326-350$ \\
\hline
\end{tabular}

Table-7: Result of Standing Broad Jump

\begin{tabular}{ccccccc}
\hline Class & Variable & n & mean & sd & min & max \\
\hline 6th & Standing Broad jump $(\mathrm{cms})$ & 71 & 141.4 & 19.78 & 105 & 185 \\
7th & Standing Broad jump $(\mathrm{cms})$ & 78 & 147.8 & 24.25 & 100 & 220 \\
8th & Standing Broad jump $(\mathrm{cms})$ & 82 & 154.8 & 20.98 & 100 & 200 \\
9th & Standing Broad jump $(\mathrm{cms})$ & 91 & 160.3 & 20.29 & 115 & 210 \\
10th & Standing Broad jump $(\mathrm{cms})$ & 17 & 157.4 & 24.27 & 100 & 195 \\
\hline
\end{tabular}

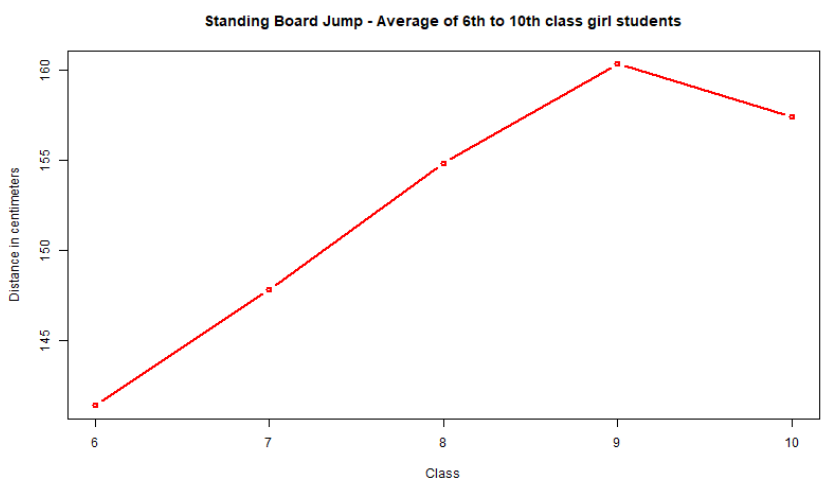

Fig. 4. Standing Broad Jump - Average of $6^{\text {th }}$ to $10^{\text {th }}$ class girl students.

Table-8: Norms for Standing Broad Jump

\begin{tabular}{cccccc}
\hline $\begin{array}{c}\text { Mar } \\
\text { ks }\end{array}$ & \begin{tabular}{c} 
6th Class \\
\cline { 2 - 6 }
\end{tabular} $\begin{array}{c}\text { Distance } \\
\text { in cm }\end{array}$ & $\begin{array}{c}\text { Distance } \\
\text { in cm }\end{array}$ & $\begin{array}{c}\text { 8th class } \\
\text { Distance } \\
\text { in cm }\end{array}$ & $\begin{array}{c}\text { 9th class } \\
\text { Distance } \\
\text { in cm }\end{array}$ & $\begin{array}{c}\text { 10th class } \\
\text { Distance } \\
\text { in cm }\end{array}$ \\
\hline 10 & $178-185$ & $209-220$ & $191-200$ & $202-210$ & $186-195$ \\
9 & $169-177$ & $197-208$ & $181-190$ & $192-201$ & $177-185$ \\
8 & $161-168$ & $185-196$ & $171-180$ & $183-191$ & $167-176$ \\
7 & $153-160$ & $173-184$ & $161-170$ & $173-182$ & $158-166$ \\
6 & $145-152$ & $161-172$ & $151-160$ & $164-172$ & $148-157$ \\
5 & $137-144$ & $149-160$ & $141-150$ & $154-163$ & $139-147$ \\
4 & $129-136$ & $137-148$ & $131-140$ & $145-153$ & $129-138$ \\
3 & $121-128$ & $125-136$ & $121-130$ & $135-144$ & $120-128$ \\
2 & $113-120$ & $113-124$ & $111-120$ & $126-134$ & $111-119$
\end{tabular}




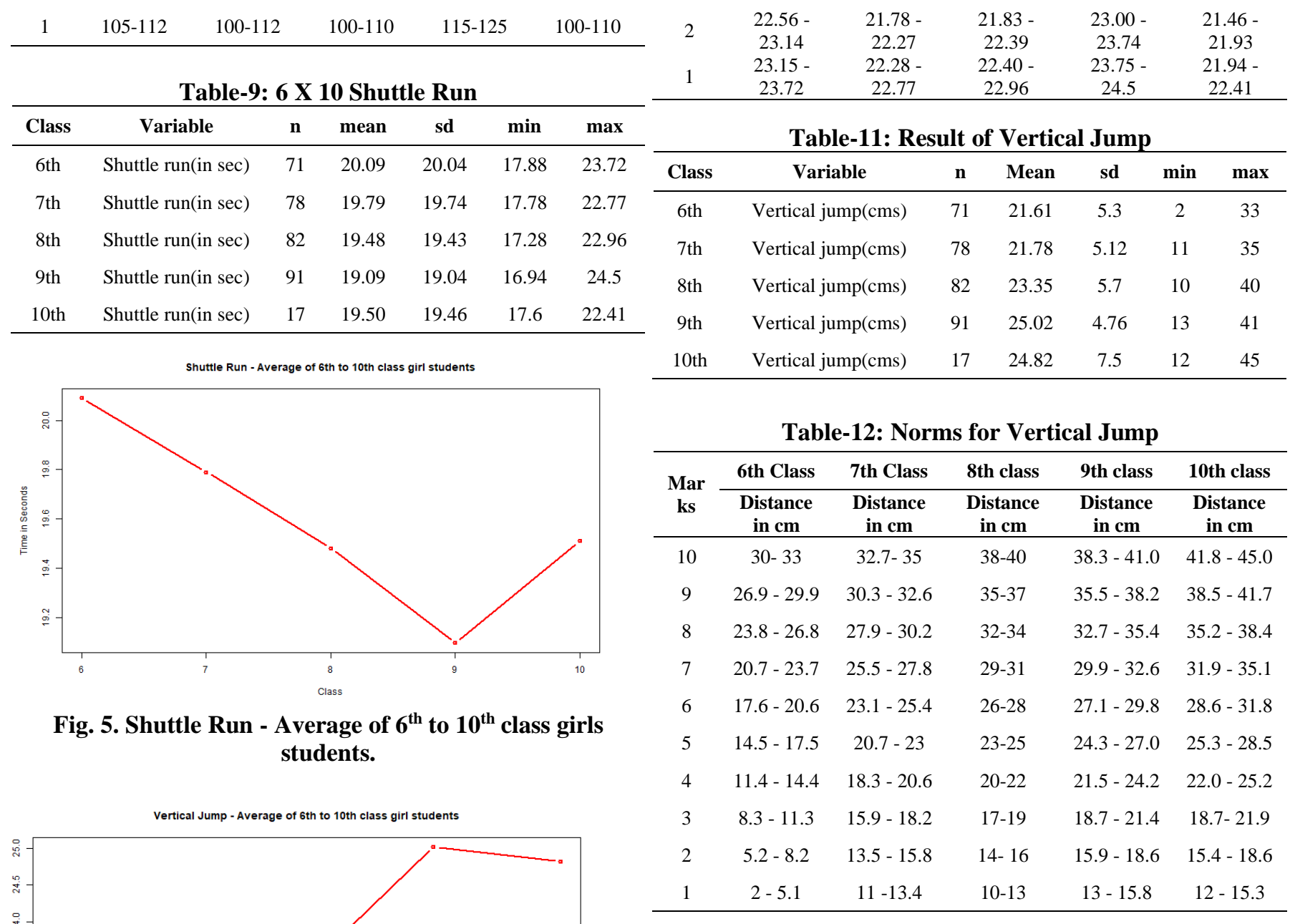

\section{Discussion And Conclusions}

Literature indicates that the physical fitness level depends on lifestyle, food habits, culture, heredity and geographical conditions and other factors. Sports Authority of India has developed physical fitness norms to identify the sports talent. But when they are used for the normal students, very few students are reaching the norms and the remaining students are getting disappointed. For classification of general students, these norms are not conducive. Hence an attempt was made to conduct study on social welfare school students.

The data indicates that the mean value $50 \mathrm{mts}$ run of the $9^{\text {th }}$ class student's was best i.e. 9.12 seconds. The result of the Bend $\&$ reach test indicates that the mean flexibility of $10^{\text {th }}$ class students was recorded as highest followed by $8^{\text {th }}$ class. The explosive strength of arms tested through medicine ball put indicates that the improvement of performance among the classes was gradually progressive from lower class to higher class. Standing broad jump results indicate that there was gradual variation with a positive increase in performance from lower class to higher class except the students of $10^{\text {th }}$ standard.

In the $6 \times 10 \mathrm{mts}$ shuttle run, the data indicates that there was a gradual improvement of performance from $6^{\text {th }}$ to $9^{\text {th }}$ class. The performance of 10 students was less than the $9^{\text {th }}$ students. The explosive strength of legs was measured with vertical jump and the result indicated that there was only a small improvement in the performance from $6^{\text {th }}$ and $7^{\text {th }}$ class students and the increment was gradually positive from $7^{\text {th }}$ to 


\section{Available online at www.ijrat.org}

$9^{\text {th }}$ class and there was a decrease in performance in case of $10^{\text {th }}$ class students. The percentiles were computed to provide a 10 point scale for each of the variable for each of the class i.e. $6^{\text {th }}, 7^{\text {th }}, 8^{\text {th }}, 9$ thand $10^{\text {th }}$ classes.

\section{CONFLICT OF INTEREST}

Yes, Researcher done study with interest only. Last three years Andhra Pradesh government was conducted sports school admission entrance test. Through physical fitness selected students will join the sports schools. Sports Authority of India constructed some norms for selection purpose. Last three years no one can reach the norms. So I interested to know the present physical fitness level of Andhra Pradesh Children.

\section{REFERENCES}

[1]. Baljinder Singh Bal, Gagandeep Singh, Kamal Kishore, Surinder Sing (2018). "Construction of physical fitness test items norms of taekwondo players of guru nanakdev university, Amritsar, India". Volume 5 | Issue 1 63-70.

[2]. Brown, L.E. \& Weir, J.P. (2001). ASEP procedures recommendations for the accurate assessment of muscular

\section{AUTHORS PROFILE}

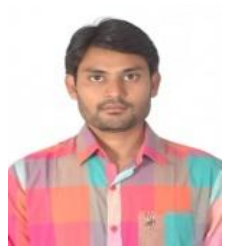

Dileep Kumar Songa received his M.P.Ed in University College of Physical Education \& Sports sciences, Acharya Nagarjuna University\& Master of Sciences (Sports Technology and Health Sciences) from Jawaharlal Nehru Technological University, Kakinadaand he is presently pursuing Ph.D in the College of Physical Education and Sports Sciences. Has 4 years of experience in the field of Physical Education and Sports Sciences.

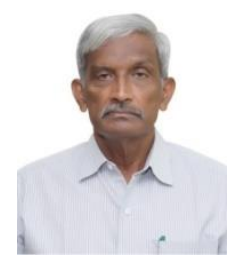

Prof. Y. Kishore (Rtd.) received his M.P.Ed in Bangalore University and he has awarded his Ph.D. in Bangalore University, Later on appointed has Asst. Prof., Associate Prof., Professor and Dean Faculty of Physical Education, Yoga \& Sports Sciences, EC Member and Registrar of Acharya Nagarjuna University.Has a 30 Years of Sports Sciences.

Experience in the field of Physical Education and

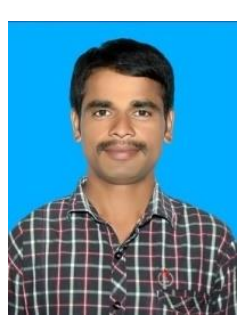

Dr. K. Sivananda received M.P.Ed and Ph.D. in Department of Physical Education and Sports Sciences, Sri Krishnadevaraya University.Working as Assistant Professor University College of Education, Sri Krishnadevaraya University.Has 5 years of experience in the field of Physical Education. strength and power. Online Journal of Exercise Physiology. 4(3): $1-21$.

[3]. Jyothilakshmi K "Construction of physical fitness norms for junior and senior high school boys and girls of Andhra Pradesh" PhD.Thesis, Dept. Physical Education, Tamilnadu Physical Education and Sports University, India, 2016.

[4]. Mahendrasinh K Mandora (2016) Associate Professor Department of Physical Education. "Construction of Physical Fitness Norms for College Students of Gujarat State", International Journal of Multidisciplinary Allied Research Review and Practices, Volume 3, Issue 4, IJMARRP Page 532.

[5]. Ramesh, Physical Director, (May 2019), "Construction of Physical fitness norms for 13-15 years high school boys". International Journal of innovative Science and Research Technology, ISSN: 2456-2165 Volume 4, Issue 5 page-1009-1011.

[6]. Surinder Singh, Gurjit Singh, Baljinder Singh Bal (2018) "Norm's construction for Physical fitness test items of handball payers". IJPNPE 2018; 3(1): 2015-2018.

[7]. Yuvraj Singh Dasondhin and Dr. Ajay Karkare (2016), Strength \& Conditioning Coach, Vidarbha Cricket Association Academy, VCA Stadium, Civil Lines, Nagpur, Maharashtra, India, "Construction of Physical Fitness Test Norms for Under 16 Cricketers in Central Zone", PARIPEX - INDIAN JOURNAL OF RESEARCH, January, 138. 